\title{
NILAI-NILAI PENDIDIKAN ISLAM \\ DALAM BUDAYA PERNIKAHAN \\ MASYARAKAT KAJANG BULUKUMBA
}

\section{Ilham Muchtar \& Asniati *}

Fakultas Agama Islam Universitas Muhammadiyah Makassar Email: ilham_em@yahoo.com, ilhammuchtar@unismuh.ac.id INFO ARTIKEL ABSTRAK

Nilai-nilai pendidikan Islam berorientasi pada pembentukan individu yang religius, bermoral dan berbudaya. Nilai-nilai tersebut meliputi tiga nilai pokok, yaitu: nilai i’tiqadiyah, nilai ubudiyah, nilai khuluqiyah. Budaya sebagai salah satu aspek pendidikan juga memiliki nilai-nilai yang disepakati dan tertanam dalam suatu lingkungan masyarakat, yang telah mengakar pada kebiasaan, kepercayaan dan simbol-simbol sebagai acuan perilaku bagi suatu masyarakat. Kajang sebagai salahsatu suku dengan ciri khas dan keunikan budayanya menarik untuk dikaji terkait wujud nilai-nilai pendidikan Islam pada budaya pernikahan di masyarakat Kajang. Dalam pandangan masyarakat Kajang, pernikahan adalah sesuatu yang suci, yang sebisa mungkin hanya dilakukan sekali saja seumur hidup. Orang yang menikah dua kali atau lebih tanpa disebabkan oleh kematian salah satu pihak, baik pihak suami ataupun istri merupakan perbuatan yang tidak terpuji. Budaya pernikahan masyarakat Kajang, tidak terlepas dari perpaduan atau keterkaitan budaya masyarakat pada umumnya di Sulawesi Selatan. Setiap rangkaian kegiatan pernikahan pada masyarakat Kajang sarat makna dan filosofi. Semua mengandung nilai doa dan harapan bagi pasangan yang akan menjalani

Kata Kunci: Nilai, Pendidikan, Pernikahan, Kajang

Keywords:

Values, Education, Marriage, Kajang kehidupan berumah tangga. Meski demikian terdapat beberapa kegiatan yang tidak sejalan dengan syariat Islam. Hal ini adalah dampak dari kepercayaan masyarakat Kajang yang mereka warisi sejak zaman dahulu dari nenek moyang secara turun temurun.

\section{ABSTRACT}

The values of Islamic education are oriented to the formation of individuals who are religious, moral and cultured. These values include three main values: i'tiqadiyah, ubudiyah and khuluqiyah. Culture as one aspect of education also has agreed values and is embedded in a community environment, which has been rooted in habits, beliefs and symbols as a reference behavior for a community. Kajang as one of the main tribes with unique cultural characteristics is interesting to study related of Islamic education values in the culture of marriage in the Kajang community. According to Kajang community, marriage is something sacred, which should only be done once in a lifetime. People who get married twice or more without being caused by the death of one of the parties, is an act that is not commendable. The marriage culture of the Kajang community is inseparable from the integration or interconnection of the culture of the community in general in South Sulawesi. Every series of marriage activities in the Kajang community is full of meaning and philosophy. All contain the value of prayer and hope for couples who will lead a married life. However there are some activities that are not in line with Islamic law. This is the impact of the Kajang people's trust which they inherited since ancient times from their ancestors from generation to generation.

\section{PENDAHULUAN}

Secara fitrah, manusia diciptakan oleh Allah swt dalam keadaan berpasangpasangan, laki-laki dan wanita. Masingmasing dari dua makhluk berlainan jenis ini dilengkapi dengan perasaan tertentu terhadap jenis yang lain di mana perasaanperasaan dan pikiran-pikiran itu ditimbulkan oleh daya tarik yang ada pada diri masing-masing, sehingga antara kedua jenis pria dan wanita itu terjalin hubungan 
yang wajar. Puncak dari hubungan perasaan keduanya adalah terjalinnya hubungan yang resmi dan sah melalui lembaga pernikahan.

Pada umumnya, pelaksanaan pernikahan yang berlaku di dalam masyarakat memiliki perbedaan antara satu dengan yang lain. Perbedaan tersebut karena adanya perbedaan budaya yang melatarbelakangi terjadinya pernikahan tersebut.

Budaya merupakan cara hidup yang berkembang, serta dimiliki bersama oleh kelompok orang, serta diwariskan dari generasi ke generasi. Menurut Deddy Mulyana dan Jalaluddin Rakhmat (2005: 26) budaya adalah suatu pola hidup menyeluruh. Budaya bersifat kompleks, abstrak, dan luas. Banyak aspek budaya turut menentukan perilaku komunikatif. Unsur-unsur sosial-budaya ini tersebar, dan meliputi banyak kegiatan sosial manusia, termasuk diantaranya adalah pernikahan.

Setiap budaya memiliki seperangkat nilai-nilai yang disepakati dan tertanam dalam suatu masyarakat, lingkup organisasi, atau lingkungan masyarakat, yang telah mengakar pada kebiasaan, kepercayaan (believe), dan simbol-simbol, dengan karakteristik tertentu yang bisa dibedakan satu dan lainnya sebagai acuan perilaku dan tanggapan atas apa yang akan terjadi atau sedang terjadi. (Koentjaraningrat dalam Warsito, 2012: 99). Nilai mengacu pada sesuatu yang oleh manusia ataupun masyarakat dipandang sebagai yang paling berharga. Jadi nilai adalah sesuatu yang bermanfaat dan berguna bagi manusia sebagai acuan tingkah laku.

Pada dasarnya, pendidikan dan budaya adalah dua hal yang berbeda. Masing-masing memiliki konsep dan orientasi tersendiri. Meski demikian, titik temu pendidikan dan budaya adalah pada aspek nilai-nilai yang ada pada keduanya. Jika nilai-nilai pendidikan diarahkan pada pembentukan pribadi manusia sebagai makhluk individu, sosial, religius, dan bermoral. Maka nilai-nilai budaya akan terlihat pada simbol-simbol, tingkah laku, serta kepercayaan yang tertanam, mengakar dan telah menjadi kerangka acuan dalam bertindak dan berperilaku.

Berdasarkan konsep di atas, menarik untuk mengkaji lebih jauh tentang nilainilai pendidikan, khususnya pendidikan Islam, yang terdapat pada budaya pernikahan pada masyarakat suku Kajang Bulukumba, Sulawesi Selatan.

\section{METODE PENELITIAN}

Penelitian ini menggunakan metode kualitatif deskriptif yang bermaksud untuk mengumpulkan informasi mengenai status suatu gejala atau keadaan yang ada, menurut apa adanya saat penelitian dilakukan. Maka penelitian ini bertujuan untuk mendeskripsikan secara sistematis, faktual dan akurat mengenai fakta-fakta, data-data, situasi atau kejadian dan karakteristik mengenai nilai-nilai pendidikan Islam yang terdapat di dalam budaya perkawinan masyarakat Kajang di Bulukumba, Sulawesi Selatan.

Mengingat pendekatan dalam penelitian ini adalah kualitatif maka instrumen utama dalam penelitian ini adalah peneliti sendiri. (Marjuni, 2012:164) Dalam pengumpulan data di lapangan sesuai dengan obyek pembahasan dalam penelitian, peneliti menggunakan instrumen pendukung, yaitu observasi, wawancara dan dokumentasi.

Sumber data melalui wawancara yang dilakukan berasal dari beberapa komponen masyarakat Kajang pada lokasi penelitian. Yaitu sebagai berikut:

\begin{tabular}{|l|l|l|l|}
\hline No & \multicolumn{1}{|c|}{ Nama Informan } & \multicolumn{1}{|c|}{ Alamat } & \multicolumn{1}{c|}{ Pekerjaan } \\
\hline 1 & Asriadi & Ds. Alorang & Penyuluh Agama \\
\hline 2 & Andi Sukman & Ds. Alorang & Tokoh Adat \\
\hline
\end{tabular}


Educandum: Volume 6 Nomor 1 Juni 2020

\begin{tabular}{|l|l|l|l|}
\hline 3 & Ra'jako & Kp. Pattinoang & Tokoh Masyarakat \\
\hline 4 & Sune' & Ds. Tanuntung & Tokoh Masyarakat \\
\hline 5 & Dedi & Ds. Gunturu & Tokoh Pemuda \\
\hline 6 & Tina & Ds. Tanuntung & Tokoh Pemuda \\
\hline 7 & Rahmatia & Ds. Tanuntung & Warga \\
\hline 8 & Eni & Ds. Singa & Warga \\
\hline 9 & Kartina & Kp. Pattinoang & Warga \\
\hline 10 & Sukmawati & Ds. Alorang & Warga \\
\hline
\end{tabular}

Data-data yang dikumpulkan kemudian dianalisa dengan menggunakan metode analisis sebagaimana konsep Miles dan Huberman. Sehingga dalam menganalisis data dimaksud terdapat tiga aktifitas yang dilakukan oleh peneliti, yaitu reduksi data (data reduction), penyajian data (data display) dan penarikan kesimpulan atau verifikasi (conclution/verification). (Sugiono, 2011: 30).

\section{PEMBAHASAN}

Nilai-Nilai Pendidikan Islam

Secara pinsip nilai pendidikan Islam tak lain adalah nilai pendidikan pada umumnya yang berorientasi pada pembentukan individu yang religius, bermoral dan berbudaya. Menurut Ruqaiyah (2006: 12) nilai-nilai pendidikan Islam terletak pada determinasi yang terdiri dari cara pandang, aturan dan norma yang ada pada pendidikan Islam yang selalu berkaitan dengan akidah, ibadah, syariah, dan akhlak. Dengan demikian, nilai pendidikan dengan corak atau sifat-sifat khusus yang bersumber dari nilai agama yang pokok adalah Alqur'an dan AsSunnah dapat disebut sebagai nilai-nilai pendidikan Islam itu sendiri.

Menurut Achmadi, (1992: 58) nilainilai utama pendidikan Islam yang seharusnya ditanamkan pada peserta didik meliputi tiga nilai pokok, yaitu: nilai i'tiqadiyah, nilai ubudiyah, nilai khuluqiyah.
Pertama: Nilai I’tiqadiyah. Nilai ini merupakan nilai yang terkait dengan akidah atau keimanan kepada Allah swt. Akidah adalah sesuatu yang mutlak diyakini secara penuh tanpa syak keraguan sebelum yang lainnya. Dalam iman terdapat 3 (tiga) unsur yang mesti berjalan serasi, antara pengakuan lisan, pembenaran hati dan pelaksanaan secara nyata dalam perbuatan. Aspek keimanan harus mendapat perhatian yang pertama dan utama dalam pendidikan. Dengan nilai keimanan ini peserta didik diharapkan kelak tumbuh dewasa menjadi insan yang dengan keimanan kuat yang bisa membentengi dirinya dari perbuatan dan kebiasaan buruk. Seyogyanya nilai-nilai iman tidak hanya dimaksudkan untuk menjadi pengetahuan semata, melainkan menjadi nilai-nilai yang dapat diimplementasikan dalam kehidupan sehari-hari.

Kedua: Nilai Ubudiyah. Nilai ini tak lain adalah wujud perbuatan yang dilandasi rasa pengabdian kepada Allah swt (ubudiyah). Ubudiyah atau ibadah merupakan kewajiban agama Islam yang tidak bisa dipisahkan dari aspek keimanan. Keimanan merupakan pundamen, sedangkan ibadah merupakan manisfestasi dari keimanan tersebut

Karena itu dalam pengertiannya yang lebih luas, ibadah mencakup keseluruhan kegiatan manusia dalam hidup di dunia ini, termasuk kegiatan 'duniawi' sehari-hari, jika kegiatan itu dilakukan dengan sikap batin serta niat pengabdian dan penghambaan diri kepada Tuhan, yakni 
sebagai tindakan bermoral. (Nurcholis Madjid, 1995: 57) Dengan demikian kualitas ibadah seseorang berbanding lurus dengan kualitas imannya. Demikian pula sebaliknya, semakin tinggi iman yang dimiliki akan semakin kuat pula tingkat ubudiyah seseorang.

Ketiga: Nilai Khuluqiyah. Akhlak bermakna perilaku atau tingkah laku yang baik atau buruk, tetapi umumnya kata akhlak berkonotasi baik. Akhlak adalah bagian yang tidak dapat dipisahkan dari pendidikan, bahkan ia adalah tujuan dari pendidikan. Akhlak juga merupakan realisasi dari keimanan yang dimiliki oleh seseorang. Lebih jauh, akhlak berhubungan dengan aktivitas manusia dalam hubungan dengan tuhannya, dengan dirinya sendiri dan orang lain serta lingkungan sekitarnya.

Ahmad Amin (dalam Hamzah Ya'kub, 1996: 12) merumuskan "akhlak ialah ilmu yang menjelaskan arti baik dan buruk, menerangkan apa yang seharusnya dilakukan oleh sebagian manusia kepada yang lainnya, menyatakan tujuan yang harus dituju oleh manusia dalam perbuatan mereka dan menunjukkan jalan untuk melakukan apa yang harus diperbuat". Dari pengertian ini dapat dijelaskan bahwa akhlak baik atau buruk sebagai opsi bagi manusia. Akhlak merupakan suatu sifat mental manusia dimana hubungan dengan Allah swt dan dengan sesama manusia dalam kehidupan bermasyarakat. Secara umum akhlak dapat dibagi kepada tiga ruang lingkup yaitu akhlak kepada Allah swt, akhlak kepada manusia dan akhlak kepada lingkungan.

Budaya Pernikahan pada Masyarakat Kajang Bulukumba

\section{Profil Masyarakat Kajang}

Kajang adalah nama salah satu suku di Sulawesi Selatan. Suku Kajang mendiami sebuah kawasan yang terletak di Desa Tana Towa, Kecamatan Kajang, Kabupaten Bulukumba, Sulawesi Selatan. Secara umum, kecamatan Kajang sebagian besar wilayahnya terdiri dari perkampungan, sawah, ladang, kebun, rawa, hutan dan tanah kosong. Kecamatan yang berada di bagian timur Kabupaten Bulukumba ini mempunyai struktur daerah berbukit. Sebagian tanahnya berbatu dan sebagian lagi tanah liat, sedang di bagian pesisir dan pinggir sungai berawa-rawa. Di kawasan bukit dan hutan mengalir sungai Raoa, di sisinya tumbuh hutan manggrove yang lebat dari muara hingga puluhan kilometer ke darat. (Hafid, 2013: 6). Secara administrasi, masyarakat Kajang menempati dua wilayah hunian yang diberi nama Ilalang Embaya (di dalam kawasan adat) dan Ipantarang Embaya (di luar wilayah kawasan adat). Kawasan adat adalah wilayah kekuasaan ketua adat yang bergelar ammatoa. (Haryati, 2013: 78)

Dari segi keyakinan, pada umumnya Suku Kajang memeluk agama Islam. Meski demikian, mereka juga mempunyai kepercayaan adat yang disebut dengan Patuntung. Patuntung berasal dari kata bahasa Makassar; tuntungi, yang berarti; mencari sumber kebenaran. Menurut Syamsurijal (2005: 35) keyakinan kepada Tuhan adalah kepercayaan yang paling mendasar dalam kepercayaan Patuntung. Suku Kajang percaya bahwa Tuhan adalah pencipta dari segala sesuatu, Maha Perkasa dan Maha Kekal.

\section{Budaya Pernikahan Masyarakat Kajang}

Secara garis besar budaya dan upacara pernikahan di masyarakat Kajang hampir sama antar satu wilayah desa dengan desa lainnya. Menurut masyarakat Kajang, perkawinan adalah sesuatu yang suci, yang sebisa mungkin hanya dilakukan sekali saja seumur hidup. Bagi masayarakat Kajang pada umumnya, orang yang menikah dua kali atau lebih tanpa disebabkan oleh kematian salah satu pihak, baik pihak suami ataupun istri, maka hal itu merupakan perbuatan yang tidak terpuji.

Oleh sebab itu, sebelum seseorang menentukan jodoh, ia harus berhati-hati benar dalam menentukan pilihannya. Sehingga tidak akan kecewa dikemudian hari setelah pernikahannya dilangsungkan. Masyarakat Kajang pada umumnya mempunyai patokan (ukuran) dalam 
memilih jodoh yang ideal. Ukuran yang dimaksud adalah penilaian seseorang ditinjau dari segi keturunan.

Seperti pada umumnya, dan khususnya masyarakat Sulawesi Selatan, maka masyarakat Kajang juga mengenal adanya stratifikasi sosial pada masyarakatnya yaitu: bangsawan (kerabat raja-raja), orang merdeka (to maradeka), orang berketurunan karaeng. Ketiga hal tersebut turut berpengaruh di dalam menentukan jodoh, artinya harus dari sesama golongan.

Jika yang dipilih adalah saudara sepupu pada derajat pertama, baik dari pihak ayah maupun ibu, maka pernikahan itu disebut assialli sampo sikali, jika pernikahan dilakukan dengan saudara sepupu kedua, baik dari pihak ayah maupun ibu, maka pernikahan disebut assialle sampo pinruang. Kendati ada aturan tidak tertulis mengenai cara mencari jodoh sebagaimana digambarkan di atas, akan tetapi hal tersebut bukanlah sesuatu yang wajib. Pernikahan dengan anggota masyarakat lainnya di luar keluarga pun dapat terjadi.

Berikut budaya-budaya pernikahan pada masyarakat Kajang Bulukumba:

\section{Budaya Pra Pernikahan.}

Pada tahap pra pernikahan ini, dilakukan beberapa kegiatan yaitu:

\section{a. Accarita Rua-rua}

Accarita rua-rua adalah kegiatan penjajakan awal yang dilakukan secara rahasia oleh seorang perempuan dari pihak laki-laki untuk memastikan apakah gadis yang telah dipilih sudah ada yang mengikatnya atau belum. Jika ternyata gadis yang ditunjuk belum terikat sama laki-laki lain maka pembicaraan dilanjutkan dengan bertanya kepada gadis tersebut tentang kesediannya untuk dilamar oleh seorang laki-laki. Namun jika ia telah terikat oleh lelaki lain (dijodohkan atau sudah dilamar) maka pantang bagi pihak laki-laki untuk melanjutkan pembicaraan pernikahan sampai adanya kejelasan status gadis tersebut.

\section{b. Pemilihan Jodoh.}

Proses paling awal menuju pernikahan adalah pemilihan jodoh. Masyarakat Kajang umumnya mempunyai kecenderungan memilih jodoh dari lingkungan kerabat sendiri karena dianggap sebagai hubungan pernikahan atau perjodohan yang ideal. Perjodohan ideal yang dimaksud adalah pernikahan antara sepupu satu kali atau dua kali. Kendati demikian, kedua jenis perjodohan tersebut di atas bukan sesuatu yang mutlak. Dewasa ini, sudah banyak pemuda Kajang yang menikah dengan gadis di luar lingkungan kerabatnya.

Selain perjodohan dengan kerabat dekat, perjodohan lain yang dianggap ideal adalah yang didasarkan pada kedudukan yang sama. Baik dari segi stratifikasi sosial yang sederajat di dalam masyarakat, atau dari segi keturunan (bangsawan atau orang biasa), latar belakang pendidikan, kedudukan di dalam struktur pemerintahan, maupun harta kekayaaan. Dalam masyarakat Kajang, peran orang tua masih sangat besar dalam memilih jodoh untuk putra atau putrinya.

\section{c. Adduta atau assuro}

Adduta atau assuro adalah kegiatan dimana pihak laki-laki mengutus beberapa orang yang dianggap tokoh, baik dari kalangan keluarga maupun selain keluarga, untuk menyampaikan lamaran kepada pihak keluarga gadis secara resmi. Kegiatan Adduta yaitu pertemuan antara kedua belah pihak keluarga untuk merundingkan dan memutuskan segala sesuatu yang bertalian dengan upacara pernikahan putra-putri mereka. Hal-hal yang dibicarakan dalam adduta tersebut diantaranya mahar (meliputi doi panaik dan sunrang) dan penentuan hari. Untuk mahar, adat yang berlaku bagi masyarakat Kajang umumnya berupa tanah atau perhiasan. Penetapan mahar sejak dahulu menjadi penanda status sosial ekonomi bagi keluarga yang menikah.

Selanjutnya kegiatan dilanjutkan dengan Adduta roak yakni mengukuhkan kembali kesepakatan-kesepakatan yang telah dibuat sebelumnya. Acara ini 
dilaksanakan di rumah pihak perempuan. Adduta roak ditandai dengan memberikan hadiah pertunangan dari pihak laki-laki yang disebut passikkok atau pengikat berupa sebuah cincin emas dan beberapa pemberian simbolis lainnya, seperti kuekue tradisional. Pada acara ini pihak lakilaki juga sudah harus menyerahkan doi panaik (uang belanja) yang jumlahnya berdasarkan kesepakatan kedua belah pihak pada pertemuan sebelumnya. Uang tersebut untuk digunakan dalam pesta pernikahan nanti.

\section{d. Akkiok}

Akkiok adalah menyampaikan berita mengenai perkawinan putra-putri mereka kepada pihak keluarga yang dekat, para tokoh masyarakat dan para tetangga. Pemberitahuan tersebut sekaligus sebagai permohonan bantuan baik pikiran tenaga maupun harta demi kesuksesan seluruh rangkaian upacara perkawinan tersebut. Sementara itu, appalele undangan adalah mengundang seluruh sanak keluarga dan handai taulan yang rumahnya jauh, baik dalam bentuk lisan maupun tertulis. Kegiatan ini biasanya dilakukan sekitar satu hingga sepuluh hari sebelum resepsi perkawinan dilangsungkan.

\section{e. Pakanre Tamma.}

Kegiatan pakanre tamma adalah kegiatan berupa acara khatam Al-Quran dan pembacaan Barazanji sebagai ungkapan rasa syukur kepada Allah swt dan sanjungan kepada nabi Muhammad saw atas terselenggaranya pernikahan tersebut. Acara ini biasanya dilaksanakan pada sore hari atau sesudah shalat ashar dan pimpin oleh seorang imam dan dihadiri oleh warga lainnya. Setelah itu, dilanjutkan acara makan bersama. Dalam adat masyarakat Kajang, setiap orang yang hadir pada acara pakanre tamma dan barzanji akan diberi sangu berupa uang dan besek berupa nasi ketan putih dan hitam serta kue-kue tradisional khas Kajang sebagai sebagai tanda terima kasih dari pihak keluarga yang mengadakan acara tersebut.

\section{f. Mappaccing.}

Pada malam menjelang hari perkawinan, kedua calon mempelai melakukan kegiatan mappaccing di rumah masing-masing. Kata mappaccing berasal dari kata paccing, yaitu daun pacar (raung burangga). Paccing dalam bahasa Konjo (bahasa masyarakat Kajang) berarti bersih atau suci. Kegiatan mappaccing dilakukan dalam rangka membersihkan diri dan agar pernikahan tersebut diberkahi oleh Tuhan Yang Mahakuasa. Acara ini dihadiri oleh keluarga, kerabat, orang-orang terhormat dan para tetangga.

Berikut adalah bahan-bahan yang dipakai dalam upacara mappaccing serta nilai filosofis yang dikandung, antara lain:

1) Paccing atau daun pacar yang melambangkan kehidupan yang selalu bersih.

2) Bantal yang melambangkan harkat atau kehormatan yang harus selalu dijaga.

3) Lipa sabbe atau sarung sutera yang melambangkan keharusan menjaga harga diri.

4) Daun pisang yang melambangkan harapan untuk hidup sejahtera.

5) Daun nangka yang melambangkan kehidupan yang dipenuhi dengan harapan baik.

6) Lilin yang dinyalakan yang melambangkan kehidupan cemerlang.

7) Beras yang dihamburkan sebanyak tiga kali yang menyimbolkan harapan agar calon mempelai hidup berkembang dengan penuh rejeki.

8) Buah kelapa melambangkan harapan agar hubungan istri/suami tetap erat.

9) Sisir yang melambangkan hati setiap pasangan selalu sederhana, tidak membeda-bedakan antara satu dengan yang lain.

10) Cermin melambangkan agar kedua mempelai selalu melihat dengan keadaan yang bersih.

11) Bedak melambangkan agar kedua mempelai selalu merawat dirinya dengan baik. 
12) Gula merah melambangkan agar kedua mempelai selalu bersikap manis atau baik kepada orang lain.

2. Budaya pada Pesta Pernikahan.

Setelah segenap rangkaian pra pernikahan dilakukan, maka kegiatan berlanjut pada acara resepsi atau pesta pernikahan. Kegiatan-kegiatannya antara lain;

a. Appanikkah.

Appanikkah atau Anikkah adalah kegiatan akad nikah yang dilaksanakan pada hari perkawinan. Calon mempelai laki-laki dengan diantar oleh kerabatnya akan berangkat ke rumah mempelai perempuan di pagi hari agar tiba di rumah mempelai perempuan tepat sebelum matahari tergelincir. Harapannya agar rezeki mereka juga tidak berkurang. Setelah sampai di rumah mempelai perempuan, maka segera dilakukan upacara akad nikah yang dihadiri oleh orang tua mempelai wanita, penghulu, kepala lingkungan, beserta keluarga mempelai perempuan. Pelaksanaan akad nikah ini dilakukan sesuai ajaran Islam yang dipimpin oleh penghulu atau orang tua perempuan.

\section{b. Mappasirusak}

Setelah proses akad nikah selesai, mempelai pria dituntun oleh orang yang dituakan di dari keluarga menuju ke dalam kamar mempelai perempuan untuk nipasirusak atau dipersentuhkan untuk pertama kalinya setelah akad. Kegiatan inilah yang disebut mappasirusak (persentuhan pertama) yaitu mempelai pria harus menyentuh salah satu anggota tubuh mempelai wanita. Kegiatan ini dianggap penting karena menurut anggapan masyarakat Kajang bahwa keberhasilan kehidupan rumah tangga kedua mempelai tergantung pada sentuhan pertama mempelai pria terhadap mempelai perempuan.

Jika sentuhan pertama dilakukan pada bagian dada maka diharapkan rejeki kedua mempelai akan banyak seperti gunung. Jika bagian ubun-ubun yang disentuh, maka mengandung makna agar wanita tunduk kepada suaminya. Jika tangan yang pertama kali disentuh maka diharapkan agar kelak rumah tangga keduanya tetap langgeng. Acara mappasirusak diakhiri dengan mempelai perempuan mencium tangan suaminya dan suami mencium dahi istrinya. Setelah acara mappasirusak selesai, kedua mempelai akan dituntun untuk duduk di kursi pelaminan yang telah disiapkan sebagai bentuk persaksian kepada khalayak ramai bahwa keduanya telah resmi menjadi pasangan suami istri.

\section{c. Upacara perjamuan}

Upacara perjamuan diadakan untuk menjamu tetamu yang datang memberi ucapan selamat dan doa restu. Perjamuan dilakukan dengan cara melantai atau lesehan. Hidangan nasi dengan berbagai lauk-pauknya serta kue-kue tradisional khas masyarakat Kajang dihidangkan di meja yang diberi alas kain yang panjang berwarna warni. Setelah upacara perjamuan selesai, rombongan pengantar mempelai pria berpamitan kepada pihak keluarga mempelai perempuan. Karena mempelai pria harus melakukan acara basa bersama mempelai perempuan.

\section{d. Lampa basa}

Lampa basa adalah kunjungan balasan untuk pertama kalinya dari pihak perempuan ke rumah mempelai pria. pengantin perempuan diantar oleh iringiringan kerabat yang biasanya membawa hadiah sarung tenun untuk keluarga suaminya. Setelah mempelai perempuan dan pengiringnya tiba di rumah mempelai pria, mereka langsung disambut oleh wali mempelai pria dan diberikan cincin emas sebagai tanda syukur. Mempelai perempuan dipersilahkan masuk ke rumah sebagai tanda penyambutan kepada keluarga mempelai pria. Setelah duduk sejenak di dalam rumah selanjutnya kedua mempelai dibawa ke pelaminan dan para tamu memberikan ucapan selamat.

\section{Budaya Pasca Pernikahan}

Setelah upacara pernikahan dilangsungkan, masih terdapat sejumlah kegiatan yang harus dilakukan sebagai bagian dari adat pernikahan, yaitu: 
a. Ziarah kubur.

Sehari setelah pernikahan berlangsung, kedua pengantin baru bersama keluarga sang istri melakukan ziarah ke kuburan leluhur. Kegiatan ini dimaksudkan sebagai penghormatan dan rasa syukur bahwa keluarga mereka telah melaksanakan pesta pernikahan. Kegiatan ziarah kubur dilakukan dengan menaburkan bunga atau daun pandan yang sudah diiris kecil yang dijadikan sebagai bunga, ditaburkan di atas kuburan para leluhur.

b. Upacara Sesajen pada Leluhur.

Upacara seperti ini dilakukan dengan membawa sesaji pada pohon yang dianggap keramat oleh masyarakat Kajang dan kepada roh-roh setempat menunjukkan bahwa apa yang diyakini oleh masyarakat tradisional Kajang yang masih saja menganut kepercayaan-kepercayaan pendahulu mereka seperti ke sumur tua dan sungai kecil. Menurut pemahaman masyarakat Kajang bahwa di tempat itu dihuni seekor gurita dan ular kecil yang merupakan leluhur mereka.

\section{c. Bangngi matoang}

Kegiatan bangngi matoang adalah berupa kunjungan kedua orang tua pengantin laki-laki bersama beberapa kerabat dekat ke rumah pengantin perempuan untuk bertemu dengan besannya. Kegiatan ini biasanya dilaksanakan pada malam hari sehari setelah pesta pernikahan selesai. Tujuannya adalah untuk bersilaturrahmi dan saling mengenal antar kedua keluarga secara lebih dekat. Dalam kunjungan tersebut, rombongan orang tua pengantin pria membawa rantang dan panci yang berisi buras, gogos (lemper) serta kue-kue tradisional untuk keluarga pengantin perempuan. Selanjutnya keluarga pengantin perempaun akan melakukan kunjungan balasan juga dengan membawa berupa kue tradisional, buras dan gogos dan lain-lain.

\section{Nilai-Nilai Pendidikan Islam dalam Pernikahan Masyarakat Kajang}

Keberagaman suku bangsa dan budaya di Indonesia menjadikan upacara pernikahan hadir dalam berbagai ciri khas budaya masing-masing. Masyarakat Kajang Bulukumba memiliki budaya pernikahan yang secara umum tidak jauh berbeda dengan masyarakat yang ada di Sulawesi Selatan. Meski demikian, budaya pernikahan pada masyarakat Kajang mengandung nilai-nilai pendidikan Islam yang patut untuk dipublikasikan. Adapun budaya pernikahan masyarakat Kajang terbagi ke dalam tiga tahap, yakni budaya pada tahap pra pernikahan, budaya pada saat pernikahan dan budaya pasca pernikahan.

Mengacu pada nilai-nilai pendidikan Islam sebagaimana dijelaskan sebelumnya, maka pada budaya pernikahan masyarakat Kajang juga meliputi tiga aspek, yaitu aspek nilai i'tiqadiyah, nilai ubudiyah dan nilai khulukiyah. Keseluruhan kegiatan budaya pernikahan di masyarakat Kajang dari proses awal sampai berakhirnya acara pernikahan tersebut dapat dibagi ke dalam tiga bagian sesuai dengan nilai-nilai pendidikan Islam, sebagai berikut:

Pertama: Aspek Nilai I'tiqadiyah.

Aqidah atau keimanan dalam Islam merupakan hakekat yang meresap ke dalam hati dan akal. Keimanan adalah pedoman dan pegangan bagi manusia dalam mengarungi kehidupan sebab dengan iman tersebut manusia dapat mengatur keseimbangan harmonis antara jasmani dan rohani. Ada beberapa budaya yang bisa dikaitkan dengan persoalan iktikad atau keimanan, seperti pemilihan jodoh, mappaccing, mappasirusak, ziarah kubur dan menyediakan sesajen untuk leluhur.

Pernikahan merupakan suatu ikatan yang suci setelah aqidah dan keimanan. Kesamaan aqidah dalam sebuah rumah tangga sangat penting, agar tujuan yang hendak dicapai antara suami dan istri dapat dipersatukan dan dapat memberikan faedah yang optimal serta sempurna tanpa ada yang kurang dan saling berbenturan. Kesamaan aqidah menjadi hal utama dalam memilih calon istri sebelum ditelusuri 
kriteria-kriteria yang lain sesuai dengan standar yang dikehendaki.

Karena itu masyarakat Kajang sangat memperhatikan aspek aqidah dalam prosesi pemilihan jodoh bagi putra-putrinya. Menurut mereka, dengan keyakinan agama yang sama maka pasangan suami istri dapat mewujudkan kehidupan yang harmonis, sakinah mawaddah wa rahmah. Hal ini sejalan dengan hadits nabi saw, "Wanita itu dinikahi karena empat hal: karena hartanya, karena kedudukannya, karena parasnya dan karena agamanya. Maka hendaklah kamu pilih wanita yang bagus agamanya (keislamannya). Dengan demikian, niscaya kamu akan beruntung." (HR. BukhariMuslim)

Aspek nilai aqidah lain dapat ditelusuri dalam budaya mappacing. Kegiatan ini adalah simbol mensucikan diri yang dilakukan pada malam menjelang hari pernikahan. Biasanya budaya mappaccing diawali dengan kegiatan barzanji. Pada acara tersebut, calon mempelai akan duduk di bagian tengah rumah dengan pakaian pengantin lalu secara bergantian kerabat dekat akan memberikan doa dan diakhiri dengan membasuhkan daun pacar di tangan calon pengantin. Dengan kegiatan mappacing diharapkan pasangan yang akan menjalani hidup sebagai suami istri dalam keadaan suci secara lahir dan bathin. Bersuci secara lahir dilakukan dengan membersihkan kotoran dan hadas, berarti setiap pasangan harus belajar bagaimana tata cara membersihkan diri dari kotoran dan hadas tersebut. Adapun bersuci secara batin adalah membersihkan jiwa dari pengaruh-pengaruh dosa, maksiat dan sifat tercela lainnya.

Budaya lainnya yang memiliki nilai aqidah adalah mappasirusak. Kegiatan mappasirusak yaitu mempelai pria menyentuh salah satu anggota tubuh mempelai wanita. Kegiatan ini dimaksudkan sebagai simbol harapan dan doa dari suami kepada istrinya. Meski demikian kegiatan mappasirusak tidaklah mutlak seorang suami menyentuh bagian tertentu dari badan istrinya. Dalam beberapa perkawinan kedua pasangan hanya saling bersalaman saat bertemu untuk pertama kalinya setelah akad nikah mereka.

Dalam tuntunan agama Islam, seorang suami memang disunatkan untuk membaca doa sambil mencium ubun-ubun ketika pertama kali bertemu istrinya. Doanya adalah, "Ya Allah, aku meminta kepada-Mu kebaikan istriku dan kebaikan apa yang ia munculkan pada pernikahan ini. Dan aku berlindung padamu dari keburukan istriku dan keburukan apa yang ia munculkan pada perrnikahan ini."(HR. Abu Daud dan Ibnu Majah)

Kegiatan lain yang memiliki nilai aqidah pada budaya pernikahan masyarakat Kajang adalah ziarah kubur. Budaya ini dilaksanakan setelah akad nikah dilaksanakan yang dimaksudkan untuk mendoakan para leluhur mereka dan juga sebagai penghormatan serta rasa syukur mereka karena telah mengadakan pesta perkawinan. Dalam pandangan Islam, melakukan ziarah kubur adalah hal yang baik selama dilakukan dengan tetap mengindahkan aturan-aturan yang ada dalam ajaran agama. Seperti mengucapkan salam, tidak menginjak kuburan dan menjaga adab-adab ziarah kubur lainnya. Meski demikian dalam Islam tidak ada ketentuan bahwa ziarah kubur harus dilakukan setelah akad nikah. Syariat Islam juga melarang seseorang memberi sesajen pada leluhur saat ziarah kubur karena perbuatan tersebut mengandung syirik.

Salah satu hikmah dari ziarah kubur adalah akan selalu mengingatkan kepada kematian dan kehidupan akhirat. Bagi pasangan suami istri yang baru menikah dengan ziarah kubur diharapkan rasa takut kepada Allah swt. Karena hidup berumah tangga adalah amanah yang harus dijalankan sesuai dengan petunjuk Allah swt.

Kedua: Aspek Nilai Ubudiyah.

Di samping nilai aqidah, nilai-nilai pendidikan Islam lainnya pada budaya pernikahan masyarakat Kajang adalah nilai ubudiyah atau ibadah. Aspek-aspek nilai tersebut antara lain terdapat pada budaya 
madduta atau massuro. Setelah seorang laki-laki menetapkan seorang perempuan sebagai calon istrinya. Selanjutnya pihak keluarga laki-laki akan mengutus beberapa kerabat untuk menemui keluarga perempuan dimaksud dalam rangka melamar atau meminangnya. Dalam ajaran Islam, melamar atau khitbah adalah hal yang harus dilakukan sebagai pertanda keseriusan pihak laki-laki untuk menikahi si perempuan.

Pada saat mengkhitbah, laki-laki boleh datang secara langsung ataupun diwakilkan. Boleh juga mengajak anggota keluarga ataupun datang sendirian. Kemudian pihak perempuan nantinya harus memberikan jawaban apakah menerima atau menolak. Nabi Muhammad saw berkata kepada seseorang yang telah meminang seorang perempuan: "Melihatlah kepadanya karena yang demikian akan lebih menguatkan ikatan perkawinan". (HR al-Tirmizi dan Nasai)

Dengan demikian, dapat disimpulkan bahwa hukum lamaran (khitbah) dalam Islam adalah sangat penting. Namun proses khitbah tentunya harus dilakukan secara syar'i sesuai aturan syariat agama. Dalam hal ini, Islam tidak mengenal istilah tunangan dan adat tukar cincin sebagaimana banyak dilakukan oleh masyarakat sekarang ini.

Dalam acara lamaran resmi ini juga, dilakukan kesepakatan antara kedua belah pihak dari keluarga calon pengantin. Kesepakatan ini menyangkut jenis mahar, jumlah uang panaik (biaya pesta), waktu pernikahan, pakaian adat dan hal-hal lain yang dianggap penting. Dalam pandangan ajaran Islam, memenuhi perjanjian atau kesepakatan adalah merupakan perintah agama dan perbuatan mulia yang harus selalu diperhatikan.

Selanjutnya budaya yang bernilai ubudiyah adalah budaya pakanretammak. ini dilakukan sebagai simbol bahwa kedua calon pengantin siap lahir secara spiritual untuk membina kehidupan rumah tangga. Dalam kegiatan ini, biasanya pihak keluarga akan menghadirkan guru mengaji waktu kecil sang calon mempelai untuk menuntunnya membaca beberapa ayat AlQur'an. Jika sang guru telah meninggal atau tidak bisa hadir, maka akan diwakili oleh tokoh agama setempat atau kerabat dekat yang dituakan. Meski secara bahasa, pakanretammak bermakna sukuran dalam rangka khataman Al-Qur'an tetapi dalam kegiatan ini hanya dibacakan beberapa ayat atau surat-surat pendek dalam Al-Qur'an. Nilai luhur yang dikandung dalam budaya ini adalah memberi semangat kepada setiap calon pengantin untuk belajar membaca AlQur'an sebelum menikah. Masyarakat akan menilai kurang baik (tidak berkah) jika ada calon pengantin yang tidak bisa membaca Al-Qur'an.

Kegiatan yang tidak luput dari nilai ubudiyah dalam pernikahan masyarakat Kajang adalah appanikkah atau akad nikah. Hubungan yang sah dan resmi antara pasangan laki-laki dan perempuan adalah melalui pintu akad nikah. Ini menandakan bahwa akad nikah sarat dengan nilai yang mulia. Hubungan yang sebelumnya terlarang dan haram menjadi halal setelah akad nikah dilaksanakan. Dengan akad nikah, pasangan laki-laki dan perempuan dapat menjaga harga diri dan agamanya. Secara tidak langsung juga menjaga nama baik keluarga besar keduanya. Di dalam hadits, Nabi Muhammad saw bersabda: "Ketika seorang hamba menikah, berarti dia telah menyempurnakan setengah agamanya. Maka bertaqwalah kepada Allah pada setengah sisanya." (HR Baihaqi)

Ketiga: Aspek Nilai Khulukiyah. Masyarakat Kajang Bulukumba sangat menekankan akhlak dalam segala aspek kehidupan, terutama menyangkut upacara adat. Mereka melaksanakan dengan benar serta menjunjung tata susila yang tinggi. Karena mereka menganggap bahwa akhlak bukanlah sekedar perilaku manusia yang bersifat bawaan lahir tetapi merupakan satu dimensi kehidupan seorang muslim yang mencakup aqidah, ibadah yang diajarkan Allah melalui perantaraan nabi-Nya.

Dalam budaya perkawinan masyarakat Kajang terdapat nilai-nilai 
akhlak yang tinggi baik diungkapkan secara nyata maupun secara simbol, misalnya dalam budaya pemilihan jodoh, akhlak perempuan menjadi fokus kedua setelah agama begitu pula sebaliknya. Perilaku keluarga kedua belah pihak turut menjadi sorotan karena mereka percaya bahwa seorang suami istri yang baik akan melahirkan keturunan yang baik pula. Di samping itu, seorang suami maupun istri yang berakhlak baik akan membawa kebaikan untuk dunia dan akhirat. Dalam upacara madduta atau massuro mengandung nilai-nilai sopan santun yang tinggi. Upacara madduta atau massuro tidak dilakukan sendiri oleh orang tua pihak lakilaki yang ingin menikah, tetapi diwakilkan kepada kerabat atau orang yang lebih dihormati serta lebih berpengalaman.

Budaya accarita Rua-rua merupakan konsep perwakilan yang digunakan masyakat Kajang melambangkan kehalusan budi, yaitu dalam menyampaikan niat. Mereka tidak bertanya langsung kepada pihak keluarga perempuan karena menurut mereka tidak sopan orang yang berkepentingan berbuat demikian.

Budaya lain yang memiliki nilai akhlak adalah akkiok. Budaya ini memiliki nilai yang luhur karena dengan mengetahui adanya kegiatan perkawinan salah satu anggota warga masyarakat maka mereka akan segera bersama-sama dan saling bahu membahu untuk membantu baik moril maupun materil hingga terlaksananya kegiatan tersebut dengan baik dan lancar. Saling tolong-menolong dalam kebaikan adalah salah satu perbuatan mulia yang diajarkan oleh ajaran agama Islam. Menurut budaya masyarakat Kajang setiap perkawinan harus diumumkan sebagai pernyataan rasa gembira meskipun hanya mengadakan syukuran, menyiarkan perkawinan merupakan sunnah rasulullah. Walimah budaya masyarakat Kajang biasanya berlangsung dua sampai tiga hari, mengingat kemungkinan tamu atau sanak kerabat yang datang dari tempat yang jauh. Hal ini diperbolehkan juga dalam islam. Masyarakat Kajang saling membantu dan bergotong royong dari awal sampai akhir acara.

Dalam rangka menjali ikatan silaturahim dua keluarga yang baru terhubung dengan pernikahan putra putri mereka. Masyarakat Kajang memiliki budaya yang dikenal dengan Lampa Basa dan Bangngi Matoang. Diharapkan hubungan antara keluarga suami dan istri tersebut akan saling mengenal satu sama lain, sehingga persaudaraan mereka semakin erat. Saat itulah kesempatan memperkenalkan kerabat dekat dari pengantin wanita seperti saudarasuadaranya. Rombongan keluarga biasanya juga membawa bingkisan sarung tenun untuk keluarga suaminya. Dalam pandangan agama, saling mengunjungi dan memberi hadiah adalah perbuatan baik dan mulia. Dalam hadisnya, Rasulullah saw bersabda: "Barangsiapa yang ingin diluaskan rezekinya dan dipanjangkan umurnya, maka sambunglah tali silaturahmi” (HR. Bukhari-Muslim).

Perbedaan dengan budaya lampa basa dengan bangngi matoang adalah pada waktu pelaksanaannya. Lampa Basa dilakukan pada hari pernikahan sedang bangngi matoang (menginap di rumah mertua) biasanya dilakukan beberapa setelah pelaksanaan pesta pernikahan. Dalam pandangan Islam, menjalin silaturrahim adalah perbuatan mulia yang dihukumi wajib, apalagi jika silaturrahim itu dilakukan pada kerabat.

Mencermati sebuah budaya pada suatu masyarakat memang perlu dilakukan kajian lebih mendalam. Setiap budaya selalu menyajikan sesuatu yang khas dan unik, karena pada umumya dia adalah sebuah proses atau hasil cipta, rasa dan hasil karya dalam upaya menjawab tantangan kehidupan yang berasal dari alam sekitarnya (Sumiah, 2003: 1). Lebih-lebih jika budaya tersebut dikaitkan dengan nilainilai pendidikan Islam.

Berbicara tentang masalah pernikahan selalu menarik, sebab banyak hal yang perlu diteliti dan dikaji dari budaya. Dalam konsep budaya pernikahan 
pada masyarakat Kajang, banyak simbol dan perlambang yang perlu dikoreksi dan diluruskan karena meskipun memiliki nilainilai pendidikan yang luhur namun ia bertentangan dengan ajaran Islam. Misalnya upacara adat untuk mencari hari dan bulan baik dalam melaksanakan akad nikah, sesaji kepada leluhur, sesaji pada pohon yang dianggap keramat dan kepada roh-roh setempat. Hal ini menunjukkan bahwa apa yang diyakini oleh masyarakat tradisional Kajang masih menganut kepercayaan-kepercayaan pendahulu mereka.

Dalam perkembangannya, dewasa ini banyak upacara adat pernikahan tidak lagi sesuai dengan filosofi awal yang sakral dan hikmat. Tetapi lebih pada hiburan dan tontonan semata. Meski begitu, nilai positif yang masih bertahan sampai sekarang adalah bahwa melalui budaya dan tradisi yang berlaku pada masyarakat Kajang, tali silaturrahim dan kekerabatan mereka tetap terjalin dengan kuat dan harmonis.

\section{PENUTUP}

Sebagai kesimpulan dari rangkaian pembahasan terkait nilai-nilai pendidikan Islam pada budaya pernikahan masyarakat Kajang, adalah sebagai berikut:

1)Islam adalah agama yang syumul (universal), agama yang mencakup semua sisi kehidupan. Tidak ada suatu dalam kehidupan ini, yang tidak dijelaskan di dalam Islam baik di dalam Al-Qur'an maupun hadits. Termasuk tata cara perkawinan yang menurut Islam yang begitu agung dan mulia, serta mengandung nilai-nilai pendidikan Islam, yang mencakup nilai i'tiqadiyah, nilai ubudiyah dan nilai khuluqiyah.

2)Budaya pernikahan pada masyarakat Kajang Bulukumba terdiri atas tiga tahap. Tahap pra pernikahan yang meliputi: pemilihan jodoh, accarita rua-rua, madduta, pengukuhan kesepakatan, akkiok, pakanretammak dan pembacaan barazanji serta mappaccing. Tahap pernikahan: akad nikah, mappasirusa. Serta pasca pernikahan, seperti ziarah kubur, lampa basa, banggi matoang dan memberi sesajen. 3)Setiap rangkaian kegiatan pernikahan pada masyarakat Kajang memiliki suatu makna dan filosofi tertentu. Ada banyak nilai yang mengandung doa dan harapan untuk kedua pengantin yang akan menjalani kehidupan berumah tangga. Upacara adat perkawinan masyarakat Kajang, tidak terlepas dari perpaduan atau keterkaitan budaya masyarakat pada umumnya di Sulawesi Selatan. Meski demikian, terlepas dari nilai-nilai filosofi yang luhur tersebut, beberapa diantaranya tidak sejalan dengan syariat Islam. Hal ini adalah dampak dari kepercayaan masyarakat Kajang yang mereka warisi sejak zaman dahulu dari nenek moyang secara turun temurun.

\section{UCAPAN TERIMA KASIH}

Penulis mengucapkan terima kasih pada semua pihak yang terlibat baik informan maupun pihak lain, yang telah membantu penulis dalam melakukan penelitian. Ucapan Terima kasih juga Kepada pimpinan redaksi dan tim redaksi jurnal Educandum yang bersedia menerima dan menerbitkan tulisan ini. Dan terimakasih kepada teman-teman yang telah membantu dan memberikan masukan kepada penulis selama menyelesaikan tulisan ini.

\section{DAFTAR PUSTAKA}

Achmadi. 2005. Ideologi Pendidikan Islam, Paradigma Humanisme Teosentris. Yogjakarta: Pustaka Pelajar.

Adhan, Syamsurijal. 2005. Islam dan Patuntung di Tanah Toa Kajang: Pergulatan Tiada Akhir. dalam Hikmat Budiman, ed., Hak-Hak Minoritas: Dilema Multikulturalisme di Indonesia. Yayasan Intereksi Bekerjasama dengan Tifa Foundation, Jakarta

Hafid, Abdul. 2013. Sistem Kepercayaan Pada Komunitas Adat Kajang Desa Tanah Towa Kecamatan Kajang Kabupaten Bulukumba. Jurnal 
Patanjala Vol. 5 No.1, Maret 2013: 119 BP. Nilai Budaya Bandung

Haryati. 2013. Menguak Nilai-nilai Tradisi

Pada Rumah Tinggal Masyarakat Ammatoa-Tanatoa Kajang di Sulawesi Selatan, INOVASI Jurnal. ISSN: 1693-9034, Volume 8, Nomor 4, Desember 2013.

Madjid, Nurcholis. 1995. Islam Doktrin dan Peradaban. Jakarta: Yayasan Wakaf Paramadina.

Muchtar, M.I. 2017. Pendidikan Karakter, Garansi Peradaban Berkemajuan. Tarbawi; Jurnal Pendidikan Agama Islam FAI-Universitas Muhammadiyah Makassar, Vol. 2, No. $2 . \quad$ (DOI: https://doi.org/10.26618/jtw.v2i02.10 32)

Mulyana, Deddy dan Jalaluddin Rakhmat. 2006. Komunikasi Antarbudaya: Panduan Berkomunikasi dengan Orang-orang Berbeda Budaya. Bandung: Remaja Rosdakarya.

Rachman, Abdul Shaleh. 2005. Pendidikan Agama dan Pembangunan Watak Bangsa. Jakarta: PT Raja Grafindo Persada.

Ruqaiyah M. 2006. Konsep Nilai dalam Pendidikan Islam. Padang Sidempuan: Makalah STAIN.

Setiady, Tholib. 2009. Intisari Hukum Adat Indonesia (Dalam Kajian Kepustakaan). Bandung: Alfabeta.

Soerjono, Soekanto. 2003. Sosiologi. Jakarta: PT Raja Grafindo Persada.

Sumiah. 2003. Islam dan Pergaulan Budaya Jawa. Jakarta: Teraju.

Sugiona. 2011. Metode Penelitian Kuantitatif, Kualitatif dan Kombinasi. Bandung: Alfabeta.

Syahatah, Husain. 2005. Mempermudah Pernikahan Suatu Keharusan. Jakarta: Pustaka Azzam.

Tholib, M. 1993. Perkawinan Menurut Islam. Surabaya: Al-Ikhlas.

Tri, Joko Prasetya. 1998. Ilmu Budaya Dasar. Jakarta: Rineka Cipta.
Wignjodipero, Soeroso. 1988. Asas-Asas Hukum Adat. Jakarta: Gunung Agung. 